\title{
Extracorporeal acidic predigestion of commercial dry diets can reduce the incidence of body deformities in the stomachless fish crucian carp (Carassius carassius L.)
}

\author{
Rafał Kamiński, Justyna Sikorska, Jacek Wolnicki
}

Received - 24 February 2021/Accepted - 18 June 2021. Published online: 30 June 2021; @Inland Fisheries Institute in Olsztyn, Poland Citation: Kamiński, R., Sikorska, J., Wolnicki, J. (2021). Extracorporeal acidic predigestion of commercial dry diets can reduce the incidence of body deformities in the stomachless fish crucian carp (Carassius carassius L.). Fisheries Aquatic \& Life 29, 62-68

\begin{abstract}
The aim of the present study was to test the hypothesis that predigesting commercial dry diets for fish with hydrochloric acid $(\mathrm{HCl})$ can contribute to the reduction of the incidence of body deformities in a stomachless cyprinid species intensively reared under controlled conditions. Two different dry diets (Carpco Crumble by Coppens International and Aller Futura by Aller Aqua), their respective variants modified with $\mathrm{HCl}$, and frozen larval chironomids (control diet) were fed as sole food sources to juvenile Carassius carassius in a recirculating aquaculture system at $25^{\circ} \mathrm{C}$ for 60 days. At the end of the experiment, visible body deformities occurred exclusively in the groups fed dry diets. The shares of deformities were significantly lower in fish groups fed the modified diets $(6.1-13.2 \%)$ as compared to those fed the original ones (74.0-87.0\%). Fish in the latter groups had significantly the highest condition factor values, which indicated a possible phosphorus deficiency. As evidenced by our results, predigesting commercial dry diets with $\mathrm{HCl}$ can be a useful method to mitigate the problem of body deformities occurring in intensively fed cyprinid species.
\end{abstract}

Keywords: feed, growth, hydrochloric acid, phosphorus, stomachless fish

R. Kamiński [ [ڤ], J. Sikorska, J. Wolnicki

Pond Fishery Department in Żabieniec, Stanisław Sakowicz Inland

Fisheries Institute in Olsztyn, Poland

E-mail: r.kaminski@infish.com.pl

\section{Introduction}

Body deformities are rare among wild fish. However, the presence of these anomalies in farmed teleosts is a persistent problem in aquaculture worldwide that has economic, biological, and animal welfare implications (Boglione et al. 2013a). The problem of body deformities in fish is complex, because they can be caused by numerous factors (Boglione et al. 2013b, Eissa et al. 2021). In farmed fish they are often associated with nutritional factors. However, susceptibility to body deformities induced by the same diet can be considerably different even among closely related species (Sikorska 2013).

Phosphorus deficiency is a nutritional factor that commonly causes body deformities in finfish aquaculture (Sugiura et al. 2004). In farmed fish, symptoms of phosphorus deficiency, including poor bone mineralization and bone malformations, are described in a variety of species (Ogino and Takeda 1976, 1978, Watanabe et al. 1980, Brown et al. 1993, Hardy et al.1993). Stomachless fish are more susceptible to phosphorus deficiency in aquaculture compared to fish with stomachs because they are less able to utilize phosphorus from fish meal, which is the major source of phosphorus in the vast majority 
of fish diets (Ogino et al. 1979). This difference probably originates from the lack of acidic digestion in the former (Ogino et al. 1979, Satoh 1991, Kaushik 1995). Acidic treatment of dry diets proved to be a simple, inexpensive method to improve dietary phosphorus availability for both stomachless fish and fish with stomachs (Vielma and Lall 1997, Sugiura et al. 2006, Hossain et al. 2007). However, it remains unclear whether this treatment can protect fish from body deformities.

The purpose of the present study was to test the hypothesis that the acidic predigestion of commercial dry diets with hydrochloric acid can decrease the incidence of body deformities in juvenile crucian carp, Carassius carassius (L.), a stomachless cyprinid fish that is considerably susceptible to body deformities.

\section{Material and methods}

\section{Fish}

Juvenile C. carassius individuals at the age of 5 months after hatching were used as experimental fish in the 60-day experiment. The fish were obtained from a commercial hatchery as larvae 4 days post hatch. They were reared for 5 months under controlled conditions in the laboratory of the Inland Fisheries Institute in Żabieniec at $22-25^{\circ} \mathrm{C}$. For the initial 3 weeks of their exogenous feeding, the larvae received Artemia sp. nauplii, and frozen larval Chironomidae were used later on. At the beginning of the experiment juvenile $C$. carassius had a mean

Table 1

Initial characteristics for experimental fish, stocking density, and feeding

\begin{tabular}{ll}
\hline \hline Parameter & Mean $\pm \mathrm{SD}$ \\
\hline \hline Initial mean total length $(\mathrm{mm})$ & $31.8 \pm 1.5$ \\
Initial mean body weight $(\mathrm{g})$ & $0.38 \pm 0.05$ \\
Initial condition factor $\mathrm{K}$ & $1.18 \pm 0.08$ \\
Initial stocking density (fish $\mathrm{l}^{-1}$ ) & 1.25 \\
Initial feeding ration $\left(\%\right.$ of fish biomass d ${ }^{-1}$ ) & larvae of Chironomidae 50.0; dry diets 5.0 \\
Final feeding ration $\left(\%\right.$ of fish biomass d $\left.{ }^{-1}\right)$ & larvae of Chironomidae 24.0; dry diets 1.9 \\
\hline \hline
\end{tabular}

total length (TL) of $31.8 \mathrm{~mm}$ and a mean body weight (BW) of $0.38 \mathrm{~g}$ (Table 1).

There were five treatment groups in triplicate. Each of them was fed a different diet: group $\mathrm{N}$ - natural feed of frozen larval Chironomidae; group $\mathrm{CO}$ - original commercial dry feed Carpco Crumble by Coppens International; group FO - original commercial dry feed Aller Futura by Aller Aqua; groups CM and FM - respective dry feeds modified with the hydrochloric acid treatment. The proximate composition of the basal diets is shown in Table 2. The fish were fed manually with equal portions of food 5 times daily from 08:00 to 20:00.

\section{Treatment of dry diets}

Hydrochloric acid ( $\mathrm{HCl})$ was chosen for the experimental treatment of the dry diets for the following reasons: 1) it is naturally secreted by fishes with functional stomachs; 2) it is used widely in the food industry; 3) it is relatively inexpensive.

The dry feeds were sprayed with $100 \mathrm{ml}$ of distilled water in the control groups (CO and FO) or the same volume of a food grade hydrochloric acid water solution containing $15.1 \mathrm{~g}$ of the active agent (groups $\mathrm{CM}$ and FM) per $1 \mathrm{~kg}$ of feed. The feeds were then $40^{\circ} \mathrm{C}$, until the weight of the dried feeds was approximately $1.000 \mathrm{~g}$ for groups $\mathrm{CO}$ and FO and $1.015 \mathrm{~g}$ for groups CM and FM. This treatment allowed the feed to reach its initial moisture content and the final

\section{Experimental groups} thoroughly stirred and dried for about 48 hours at 
Table 2

Proximate composition of basal experimental diets

\begin{tabular}{llll}
\hline \hline Fish diet & Larvae of Chironomidae & Carpco Crumble (Coppens Int.) & Aller Futura (Aller Aqua) \\
\hline \hline Total P content (\%) & 0.16 & 1.8 & 1.21 \\
Total lipids (\%) & 0.76 & 15.0 & 12.0 \\
Crude protein (\%) & 9.18 & 56.0 & 64.0 \\
Fibre (\%) & - & 1.4 & 0.5 \\
Caloric value $\left(\mathrm{kJ} \mathrm{g}^{-1}\right)$ & 3.22 & 16.7 & 20.8 \\
\hline \hline
\end{tabular}

All data on wet weight basis

supplement of $\mathrm{HCl}$ was about $1.5 \%$ of the fresh diet weight. The prepared feeds were stored under refrigeration throughout the experiment.

\section{Experimental procedures and conditions}

Fifty fish were stocked into 15 20-1 flow-through (0.2-0.3 $\left.1 \mathrm{~min}^{-1}\right)$ glass aquaria that were incorporated in a recirculating aquaculture system (RAS). The aquaria were illuminated by fluorescent tubes between 08:00 and 21:00 at an intensity of about $700 \mathrm{~lx}$ at the water surface. Water temperature and oxygen content were measured twice daily. The water temperature was $25^{\circ} \mathrm{C}$ (range \pm 0.5 ). Oxygen content in the water was always maintained above $60 \%$ saturation. The ammonia and nitrite contents in the water and its $\mathrm{pH}$ were monitored weekly. The values of these parameters did not exceed $0.2 \mathrm{mg} \mathrm{l}^{-1}$ and $0.02 \mathrm{mg} \mathrm{l}^{-1}$, respectively, and the water $\mathrm{pH}$ ranged from 7.8 to 8.3.

All the fish were counted and measured individually for body weight (BW) and total length (TL). They were also examined for body deformities (scoliosis, kyphosis, lordosis, skull deformities) at the termination of the experiment.

\section{Statistical analyses}

Statistical analyses were performed with Statistica 8 (StatSoft Inc., USA). The percentages of fish with visible deformities were normalized with the arcsine square root transformation and compared as a dependent variable. The normality of distribution was tested with the Shapiro-Wilk test, while the homogeneity of variance was tested with Levene's test. The statistical differences were tested with ANOVA, followed by Tukey's HSD test at $\mathrm{P}<0.05$.

\section{Results}

No mortality occurred during the experiment. Body deformities were recorded in all the groups fed the original and acid-treated dry diets (Figs. 1 and 2). The highest shares of fish with deformities were recorded in those fed the original dry diets at $74 \%$ and $87 \%$ in groups $\mathrm{CO}$ and FO. In groups $\mathrm{CM}$ and FM, which were fed the modified diets, the respective values were $13 \%$ and $6 \%$.

The lowest final mean values for TL and BW were noted in group N (Table 3). No significant difference was found for mean TL values in any of the

Table 3

Final fish characteristics for total length (TL), body weight (BW), and condition factor K

\begin{tabular}{llllll}
\hline \hline Group & $\mathrm{N}$ & $\mathrm{CO}$ & $\mathrm{CM}$ & FO & FM \\
\hline \hline TL $(\mathrm{mm})$ & $56.6 \pm 2.2^{\mathrm{b}}$ & $58.5 \pm 4.4^{\mathrm{ab}}$ & $58.0 \pm 5.4^{\mathrm{ab}}$ & $58.9 \pm 4.3^{\mathrm{ab}}$ & $59.4 \pm 5.8^{\mathrm{a}}$ \\
BW $(\mathrm{g})$ & $2.83 \pm 0.37^{\mathrm{c}}$ & $3.54 \pm 0.98^{\mathrm{ab}}$ & $3.19 \pm 0.97^{\mathrm{bc}}$ & $3.61 \pm 1.00^{\mathrm{a}}$ & $3.31 \pm 0.97^{\mathrm{abc}}$ \\
K & $1.55 \pm 0.08^{\mathrm{b}}$ & $1.71 \pm 0.10^{\mathrm{a}}$ & $1.57 \pm 0.10^{\mathrm{b}}$ & $1.72 \pm 0.10^{\mathrm{a}}$ & $1.53 \pm 0.09^{\mathrm{b}}$ \\
\hline \hline
\end{tabular}

Values are means \pm SD. Values in a row not sharing a letter are statistically different (Tukey's HSD test, $p<0.05$ ). 


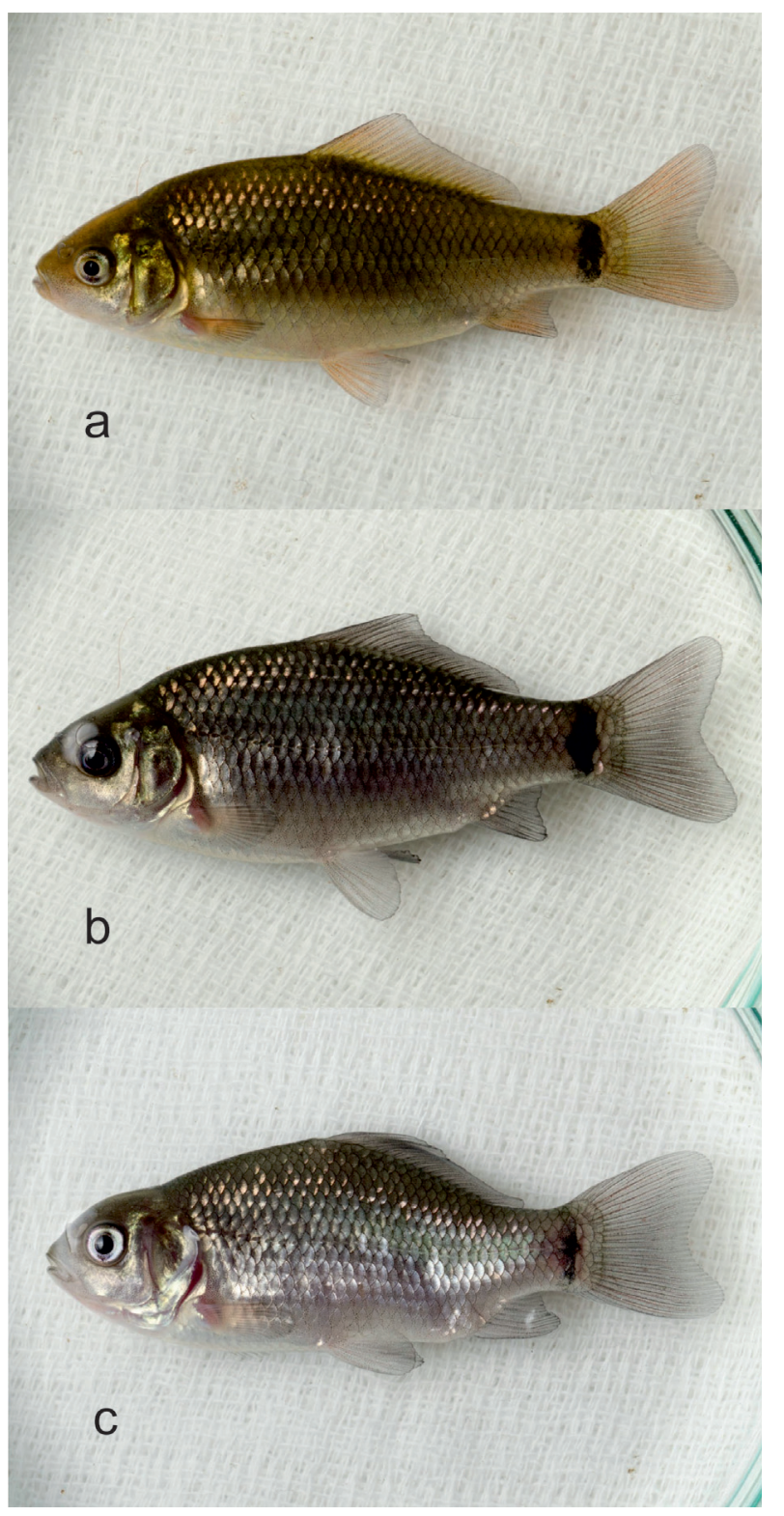

Figure 1. Juvenile $C$. carassius individuals fed different diets: a) chironomid larvae; b) acid-predigested Aller Futura dry diet (no visible body deformities), c) original Aller Futura dry diet (numerous visible body deformities).

groups fed the original or modified dry diets. The highest final mean BW values were noted in groups $\mathrm{CO}, \mathrm{FO}$, and FM, and they ranged from 3.31 to 3.61 g. The highest mean condition factor $\mathrm{K}$ values of 1.71-1.72 were recorded in fish from groups $\mathrm{CO}$ and $\mathrm{FO}$, whereas in the remaining groups values for $\mathrm{K}$ were significantly lower at 1.53-1.57.

\section{Discussion}

The use of acids and their salts as fish diet acidifiers has a long history in aquaculture. Most often diet acidification results in better fish growth, better food utilization, and increased disease resistance (reviews Lückstädt 2008a, 2008b). While the mechanisms of these effects remain unclear, in many cases higher stomach enzyme activity and the increased availability of energy carried by organic acids were identified as possible factors. However, these explanations were not entirely suited to stomachless fish, such as cyprinids. In these fish, food is naturally digested at semi-neutral $\mathrm{pH}$ values or even in a slightly alkaline environment. Since $C$. carassius food is digested at a pH range of 6.50-7.61 (Solovyev et al. 2018), acidifying diets for this species might not increase enzyme activity.

Acidifying dry feeds is also hypothesized to be effective in improving of the availability of minerals contained in fish meal (Sugiura et al. 1998). Fish meal is often a P-rich, major ingredient of commercial feeds for these animals that contains high amounts of P bound in secondary and tertiary calcium phosphates, which is poorly absorbed by stomachless cyprinid fish species (Ogino et al. 1979). In contrast to calcium (Ca) and magnesium $(\mathrm{Mg})$, dietary $\mathrm{P}$ is the main source of this macromineral for fishes (Lall 2002). Therefore, the low availability of dietary $\mathrm{P}$ can cause deficiencies of this element in fishes. Long term P deficiency in fishes can, in turn, induce body deformities.

In numerous feeding trials lasting 60 days or longer, high shares of body deformities were detected in cyprinid fish species prone to deformities that were fed intensively with commercial diets under controlled conditions (Myszkowski et al. 2002, Wolnicki 2005, Kamler et al. 2006, 2008, González-Rodríguez et al. 2014, Kamiński et al. 2017). Likewise, in the current 60-day experiment, very high shares of fish with visible deformities were found in both groups fed the original dry diets (74.0 and 87.0\%). However, predigesting these diets with $\mathrm{HCl}$ resulted in 


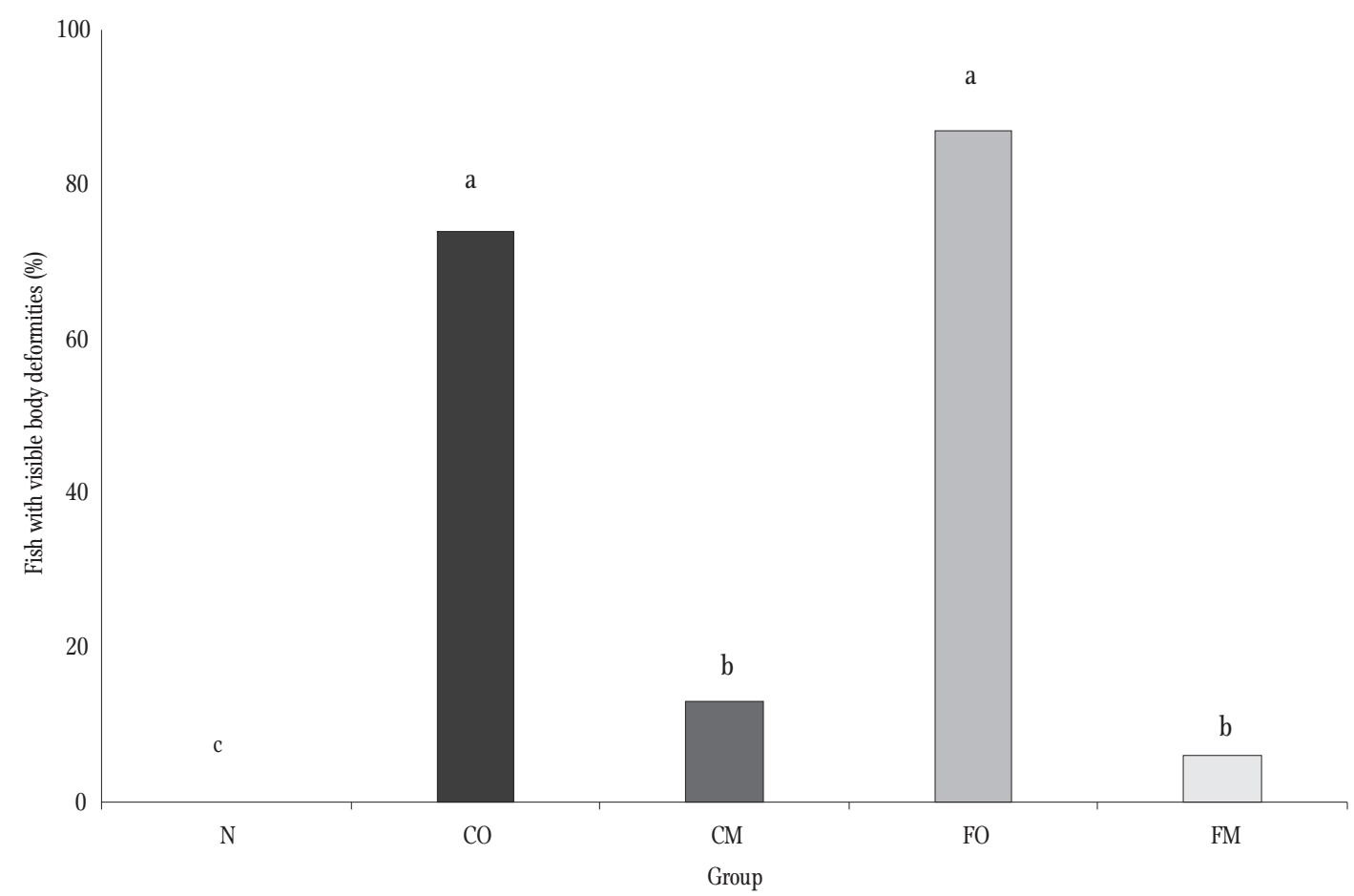

Figure 2. Final share of $C$. carassius juveniles with visible body deformities in groups fed different diets for 60 days ( $\mathrm{N}$ - chironomid larvae, $\mathrm{CO}$ - original Carpco Crumble by Coppens Int., CM - Carpco Crumble diet predigested with HCl, FO - original Aller Futura diet by Aller Denmark, FM - Aller Futura diet predigested with $\mathrm{HCl}$ ).

substantially lower incidences of body deformities (Fig. 2).

In the present study, the acidic predigestion of dry diets did not have a significant influence on fish growth, but there was a notable tendency for lower body weights in fish fed the predigested diets with acid as compared to those fed the respective original diets (Table 3). Pronounced differences in the final values of condition factor $\mathrm{K}$ were determined between the highest mean values found in groups fed original dry diets (1.71-1.72) and groups fed natural food or modified diets (1.53-1.55). In numerous fish species, including $C$. carassius, high values of $\mathrm{K}$ were a symptom of the excessive accumulation of lipids and general deficiency of macrominerals (Myszkowski et al. 2002, Helland et al. 2005, Kamler et al. 2006; Baeverfjord et al. 2008). High K values can also indicate phosphorus deficiency in fishes (Sugiura et al. 2004). Therefore, the low values of factor $\mathrm{K}$ should be considered a positive result of feeding fish the modified dry diets. This seemed to indicate that predigesting dry diets with $\mathrm{HCl}$ resulted in increased dietary phosphorus availability to the fish and, in turn, to subsequent decrease in the incidence of fish deformities. This finding contrasts with results obtained for cyprinid goldfish (C. auratus), where supplementing the dry diet with $5 \%$ citric acid resulted in reduced feed intake and decreased values of the apparent availability of phosphorus (Sugiura et al. 1998). Therefore, further research is needed to better understand how different organic and inorganic acids influence the bioavailability of dietary $\mathrm{P}$ for cyprinid fishes.

Author contributions. R.K. conceived and co-designed the study, performed laboratory work and data analysis, and wrote the paper; J.S. co-designed the study, performed laboratory work, and participated in writing the paper; J.W. co-designed the study, performed laboratory work, participated in writing the paper.

Acknowledgments. The study was supported from Project S-001 of the Stanisław Sakowicz Inland Fisheries Institute in Olsztyn, Poland. All photographs were taken and processed by Michał Kamiński. 


\section{References}

Baeverfjord, G., Hjelde, K., Helland, S., Refstie, S. (2008). Restricted dietary levels of phosphorus and zinc induce specific skeletal deformities in juvenile Atlantic salmon (Salmo salar L.). European Aquaculture Society Special Publication, 37, 52-53.

Boglione, C., Gavaia, P., Koumoundouros, G., Gisbert, E., Moren, M., Fontagné, S., Witten, P. E. (2013). Skeletal anomalies in reared European fish larvae and juveniles. Part 1: normal and anomalous skeletogenic processes. Reviews in Aquaculture, 5, 99-120.

Boglione, C., Gisbert, E., Gavaia, P., E. Witten, P., Moren, M., Fontagné, S., Koumoundouros, G. (2013). Skeletal anomalies in reared European fish larvae and juveniles. Part 2: main typologies, occurrences and causative factors. Reviews in Aquaculture, 5, 121-167.

Brown, M. L., Jaramillo Jr, F., Gatlin III, D. M. (1993). Dietary phosphorus requirement of juvenile sunshine bass, Morone chrysops + $\times$ M. saxatilis $0^{x}$. Aquaculture, 113(4), 355-363.

Eissa, A. E., Abu-Seida, A. M., Ismail, M. M., Abu-Elala, N. M., Abdelsalam, M. (2021). A comprehensive overview of the most common skeletal deformities in fish. Aquaculture Research, 52(6), 2391-2402.

González-Rodríguez, Á., Celada, J. D., Carral, J. M., Sáez-Royuela, M., Fuertes, J. B. (2014). Evaluation of a practical diet for juvenile tench (Tinca tinca L.) and substitution possibilities of fish meal by feather meal. Animal Feed Science and Technology, 187, 61-67.

Hardy, R. W., Fairgrieve, W. T., Scott, T. M. (1993). Periodic feeding of low-phosphorus diet and phosphorus retention in rainbow trout (Oncorhynchus mykiss). In: Fish Nutrition in Practice (Ed.) Kanshik S.J., Luquet P., INRA, Paris, France, 403-412.

Helland, S., Refstie, S., Espmark, Å., Hjelde, K., Baeverfjord, G. (2005). Mineral balance and bone formation in fast-growing Atlantic salmon parr (Salmo salar) in response to dissolved metabolic carbon dioxide and restricted dietary phosphorus supply. Aquaculture, 250(1-2), 364-376.

Hossain, M. A., Pandey, A., Satoh, S. (2007). Effects of organic acids on growth and phosphorus utilization in red sea bream Pagrus major. Fisheries Science, 73(6), 1309-1317.

Kamiński, R., Sikorska, J., Wolnicki, J. (2017). Diet and water temperature affect growth and body deformities in juvenile tench Tinca tinca (L.) reared under controlled conditions. Aquaculture Research, 48(3), 1327-1337.

Kamler, E., Myszkowski, L., Kamiński, R., Korwin-Kossakowski, M., Wolnicki, J. (2006). Does overfeeding affect tench Tinca tinca (L.) juveniles? Aquaculture International, 14(1), 99-111.
Kamler, E., Wolnicki, J., Kamiński, R., Sikorska, J. (2008). Fatty acid composition, growth and morphological deformities in juvenile cyprinid, Scardinius erythrophthalmus fed formulated diet supplemented with natural food. Aquaculture, 278(1-4), 69-76.

Kaushik, S. J. (1995). Nutrient requirements, supply and utilization in the context of carp culture. Aquaculture, 129(1-4), 225-241.

Lall, S. P. (2002). The minerals. In: Fish Nutrition. 3rd edition, (Ed.) Halver J.E., Hardy R.W., Academic Press Inc., San Diego, CA, USA, 259-308.

Lückstädt, C. (2008a). The use of acidifiers in fish nutrition. CAB Reviews: Perspectives in Agriculture, Veterinary Science, Nutrition and Natural Resources, 3, No. 044.

Lückstädt, C. (2008b). Utilization of acidifiers in nutrition and feeding of tropical fish-a minireview. Bulletin of Fish Biology, 10(1/2), 105-109.

Myszkowski, L., Kamiński, R., Quiros, M., Stanny, L. A., Wolnicki, J. (2002). Dry diet-influenced growth, size variability, condition and body deformities in juvenile crucian carp Carassius carassius L. reared under controlled conditions. Archives of Polish Fisheries, 10(1), 51-61.

Ogino, C., Takeda, H. (1976). Mineral requirements in fish. III - Calcium and phosphorus requirements in carp. Bulletin of the Japanese Society of Scientific Fisheries, 42, 793-799.

Ogino, C., Takeda, H. (1978). Requirements of rainbow trout for dietary calcium and phosphorus. Bulletin of the Japanese Society of Scientific Fisheries, 44, 1019-1022.

Ogino, C., Takeuchi, L., Takeda, H., Watanabe, T. (1979). Availability of dietary phosphorus in carp and rainbow trout. Bulletin of the Japanese Society of Scientific Fisheries, 45, 1527-1532.

Satoh, S. (1991). Common carp, Cyprinus carpio. In: Handbook of Nutrient Requirements of Finfish (Ed.) R.P. Wilson, CRC Pres, UK, 55-67.

Sikorska, J. (2013). Different susceptibility to body deformities in juvenile cyprinid fish intensively fed dry diet under controlled conditions. In: Diversification in Inland Finfish Aquaculture (DIFA II), (Ed.) Pšenička M., Němcová I., Dvořáková Z., Kovaříková K., Vodňany, Czech Republic, 21.

Solovyev, M. M., Izvekova, G. I., Kashinskaya, E. N., Gisbert, E. (2018). Dependence of $\mathrm{pH}$ values in the digestive tract of freshwater fishes on some abiotic and biotic factors. Hydrobiologia, 807(1), 67-85.

Sugiura, S. H., Dong, F. M., Hardy, R. W. (1998). Effects of dietary supplements on the availability of minerals in fish meal; preliminary observations. Aquaculture, 160(3-4), 283-303. 
Sugiura, S. H., Hardy, R. W., Roberts, R. J. (2004). The pathology of phosphorus deficiency in fish a review. Journal of Fish Diseases, 27(5), 255-265.

Sugiura, S. H., Roy, P. K., Ferraris, R. P. (2006). Dietary acidification enhances phosphorus digestibility but decreases $\mathrm{H}+/ \mathrm{K}+$-ATPase expression in rainbow trout. Journal of Experimental Biology, 209(19), 3719-3728.

Vielma, J., Lall, S. P. (1997). Dietary formic acid enhances apparent digestibility of minerals in rainbow trout,
Oncorhynchus mykiss (Walbaum). Aquaculture Nutrition, 3(4), 265-268.

Watanabe, T., Murakami, A., Takeuchi, L., Nose, T., Ogino, C. (1980). Requirement of chum salmon held in freshwater for dietary phosphorus. Bulletin of the Japanese Society of Scientific Fisheries, 46, 361-367.

Wolnicki, J. (2005). Intensive rearing of early stages of cyprinid fish under controlled conditions. Archives of Polish Fisheries, 13 (Suppl. 1), 5-87 (in Polish). 